\title{
A barlangi adaptáció hatása közönséges víziászka (Asellus aquaticus) táplálékpreferenciájára
}

\author{
HAFENSCHER VikTória Priszcilla ${ }^{1,2 *}$, HORVÁTH Gergely ${ }^{1}$, \\ BALÁZS GERGELY ${ }^{1}$ és HERCZEG GÁBOR ${ }^{1}$ \\ ${ }^{1}$ Viselkedésökológiai Csoport, Állatrendszertani és Ökológiai Tanszék, Eötvös Loránd Tudományegyetem, \\ 1117 Budapest, Pázmány Péter sétány 1/C \\ ${ }^{2}$ Társadalom- és Gazdaságföldrajzi Tanszék, Eötvös Loránd Tudományegyetem, 1117 Budapest, \\ Pázmány Péter sétány 1/C *E-mail: haf.viktoria@gmail.com
}

\begin{abstract}
Összefoglalás. Az egyik legplasztikusabb fenotípusos jelleg a viselkedés, az új élőhelyek meghódítása során pedig kulcsfolyamat a viselkedési innováció, ami fejlettebb kognitív képességeket és idegrendszert igényel, ezért költségei is vannak. Kutatásunk során azt vizsgáltuk, hogy egy táplálék- és élőhely-generalista faj, miután adaptálódott egy viszonylag stabil élőhelyhez, elveszti-e a táplálékváltást segítő innovációs készségét. Ehhez egy manipulatív kísérletet végeztünk, modellállatként a közönséges víziászka (Asellus aquaticus) felszíni és barlangi populációit használtuk. Hipotézisünk az volt, hogy a barlangi, stabilabb környezetben, kisebb a viselkedési innovációs készség. A kísérletek során azonban nem ezt tapasztaltuk.
\end{abstract}

Kulcsszavak: barlangkolonizáció, adaptáció, fenotípusosos változatosság, táplálékpreferencia, környezeti stabilitás.

Elfogadva: 2019.11.20.

Elektronikusan megjelent: 2019.12.11.

\section{Bevezetés}

FISHER egyszerü és statikus nézőpontja alapján azt várnánk, hogy a populációk átlagos fenotípusát a szelekció egy adaptív optimum felé tolja, melynek hatására a populáción belüli változatosság alacsony marad (FISHER 1930, 1958). A való életben azonban azt látjuk, hogy a populáció a fenotípusos jellegeket tekintve változatos, nem egy szük optimum körül ingadozik. A fenotípusos plaszticitás egy genotípus azon képességét jelenti, hogy különböző környezetekben különböző fenotípusokat hozhasson létre, amit gyakran nehéz elkülöníteni az evolúciós mintázatoktól (WENNERSTEN \& FORSMAN 2012).

A földfelszíni és földfelszín alatti élőhelyek összehasonlítása nagyszerü lehetőséget biztosít annak tesztelésére, hogy az alacsony környezeti változatosság csökkent fenotípusos változatosságot okoz-e. A barlangok speciális és elszigetelt élöhelyek, melyek jellemzően nagymértékben eltérnek a közvetlen környezetükben lévő felszíni környezettől. Homogénebbek és kevésbé változatosak mind az abiotikus, mind a biotikus környezeti tényezőket tekintve, mint a felszíni környezet (BARR \& HOLSINGER 1985, CULVER \& PIPAN 2019). 
Nincs napszakos periodicitás, és ugyanígy az évszakok is hiányoznak. A barlangok további jellemzője az állandó sötétség, és viszonylagos állandó hőmérséklet. Szegényes a trofikus szintezettség, termelők sokszor abszolút nincsenek (BARR 1967).

Kutatásunk célja a fenotípusos változatosság különbségeinek vizsgálata barlangi és felszíni populációk összehasonlításával. Tesztelni kívántuk, hogy egy táplálék és élőhely szempontjából generalista fajnak elveszik-e a táplálékváltást segítő innovációs készsége, miután egy alacsony komplexitású élőhelyhez alkalmazkodott, melynek fizikai struktúrája egyszerü, a hőmérséklet egész évben állandó, az életközösség leegyszerüsödött és csupán egyféle tápláléktípus elérhető. Modellfajként a közönséges víziászkát (Asellus aquaticus LINNAEUS, 1758, Crustacea, Isopoda) választottuk, mely Európa-szerte elterjedt az édesvizekben, és populációi egymástól függetlenül többször, sikeresen hódítottak meg földalatti élőhelyeket (VEROVNIK et al. 2005). A barlangi populációkon szembetünő a troglomorf habitus, vagyis a pigmentáció elvesztése, az ommatidák visszafejlődése, és a csáp hosszának növekedése (PREVORCNIK et al. 2004). Magyarországon a közönséges víziászka egyetlen ismert barlangi populációja a Budán található, kemoautotróf Molnár János-barlangban él (BORSODI et al. 2012). A barlangi tavat karsztos hévíz táplálja, így a hőmérséklete évszaktól függetlenül $24^{\circ} \mathrm{C}$ körül mozog (KENDER 1939); emellett a kemoautotróf aktivitású baktériumok táplálékként szolgálnak a víziászkáknak, ezzel önálló termelői szintet hozva létre más barlangokkal ellentétben, ahol csak kívülröl kerül be az alsó trofikus szint. Mivel a viselkedés flexibilitásának fenntartása energiaigényes, és barlangi, viszonylag állandó környezet esetében feltételezzük, hogy nem igényel nagy viselkedési flexibilitást, azt várjuk, hogy a szelekció a viselkedés flexibilitásának csökkenése felé tolja a populációt.

Kutatásunk munkahipotézise, hogy a barlangi állandó környezetben a viselkedési flexibilitásnak általában és a flexibilitás extrém formájaként is értelmezhető innovációknak a jelentősége feltételezhetően alacsony és ezért az innovációra való hajlam csökken, esetleg el is tünik a barlangi környezethez való alkalmazkodás során. A viselkedési innovációnak két fő típusát különíthetjük el: technikai innováció (új viselkedési mechanizmus) és forrás innováció (új forrás használata) (OVERINGTON et al. 2009). Az általunk vizsgált gerinctelen fajnál inkább a második típus várható, ezért a kutatásunkban tesztelt predikció a következő: a felszíni, sokféle táplálékot fogyasztó víziászkák gyorsabban váltanak a specifikus barlangi táplálékforrásra, mint a barlangi, egyféle táplálékot fogyasztó ászkák a felszíni táplálékforrásra.

\section{Anyag és módszer}

\section{Kísérleti állatok}

A gyüjtés 2018. augusztus 15-17. között történt, amikor a felszíni mintavételi helyek vízhőmérséklete nagyjából megegyezett a Molnár János-barlang tavának hőmérsékletével, nagyjából $23-24{ }^{\circ} \mathrm{C}$ körüli. Három felszíni, valamint egy barlangi populációból gyüjtöttünk 50-50 egyedet, hímeket és nőstényeket egyenlő arányban $(25+25)$. Felszíni mintavételi területeink a Csömöri-patak (47³5'35.03"N 1907'21.78"E), a Dunakeszi-tőzegtavak (4736'23.15"N 1907'24.63"E), valamint a Malom-tó (47³1'05.09"N 1902'09.19"E) vol- 
tak. A barlangi populáció egyedei a Molnár János-barlangból (47³1'05.09"N 1902' 09.19"E) származnak, mely összeköttetésben áll a Malom-tóval, az eddigi vizsgálatok alapján azonban a felszíni és barlangi populáció között nincs génáramlás (PÉREZ-MORENO et al. 2017). A gyüjtést egyeléses módszerrel végeztük, felszíni élőhelyeken a vízből, vagy vízi növényzetből, a Molnár János-barlangban pedig egy speciálisan erre a célra kifejlesztett szippantót használtunk, minimalizálva ezzel az állatok sérülésének kockázatát. A mintavételi helyszínekről az élőhelynek megfelelő táplálékot (felszín: vízbe hullott nyárfalevél avar (Populus sp.), mivel ez volt legnagyobb mennyiségben jelen levő közös táplálékforrás; barlang: baktériumfilm), valamint vizet is gyüjtöttünk. Fontos megjegyezni, hogy a Molnár János-barlangban lévő populáció számára az egyetlen elérhető táplálékforrás a baktériumfilm, míg a felszíni populációk széles táplálékspektrumot fogyasztanak.

Az állatok közvetlenül a gyüjtést követően az ELTE Biológia Intézetben helyet kapó barlangbiológia laborba kerültek, ahol az egyes egyedek nemét sztereomikroszkópos vizsgálattal állapítottuk meg, majd egyesével, egyedi kóddal ellátott Petri-csészékben (átmérő: $85 \mathrm{~mm}$; magasság: $24 \mathrm{~mm}$ fedő nélkül) helyeztük el őket. A Petri-csészék alját belül csiszolópapírral felcsiszoltuk, biztosítva ezzel a víziászkák akadálytalan helyváltoztatását az érdes felszínen. Minden egyedet az élőhelyéről származó vízben tartottunk, a vízszint kb. a tartóedény magasságának feléig ért. Ezt követően az egyedeket populációnként speciális kamrákba helyeztük, melyek fedőlapjának belső peremén kétoldalt 1-1 fényforrás helyezkedett el, melyek természetes spektrumú fényt (színhőmérséklet: $4500 \mathrm{~K}$ ) bocsátottak ki. A kamrák belsejébe infravörös felvételek készítésre alkalmas, átalakított webkamerákat szereltünk, a felvételekhez szükséges fényforrások a kamrák aljzatába voltak beszerelve. Fontos megjegyezni, hogy az ezek által kibocsátott hullámhosszt $(900 \mathrm{~nm})$ a víziászkák nem képesek érzékelni (KOHLER et al. 2018). A kamrák oldalfalai átlátszatlan fekete müanyaglapokból készült borítással voltak szigetelve, így szivárgó fény sem a külvilágból sem a dobozokból nem juthatott be illetve ki. A felszíni populációk esetében a felső fénycsövek az évszaknak megfelelő megvilágítási időt biztosítottak (16h nappal - 8h sötét), míg a MolnárJános barlangból származó egyedeket állandó sötétségben tartottuk.

\section{Kísérleti elrendezés}

A kísérletek augusztus 24 és 27 között zajlottak, egy 48 órás aklimációs időszakot követően. Közvetlenül a kísérletek előtt egy órával minden egyed pozícióját randomizáltuk egy kamrán belül és a Petri-csészék közepére gumigyürüket helyeztünk (átmérö: $5 \mathrm{~mm}$; magasság: $1 \mathrm{~mm}$ ), melyek a táplálékforrás kezdeti pozíciójának standardizálására szolgálták, a víziászkákat azonban nem gátolták a táplálkozásban. Minden egyedet a saját természetes környezetében teszteltünk, így a felszíni populációkat fehér fényben, míg a Molnár Jánosbarlangból származó egyedeket sötétben. A felvételeket az OBS Studio program segítségével készítettük. A felvétel az első táplálék behelyezésével egy időben indult és az utolsó táplálék behelyezése után 60 percig futott.

A tesztek során az egyedek fele az élőhelyének megfelelő táplálékforrást (felszíni egyedek avart, barlangi egyedek baktériumfilmet), másik fele számára ismeretlen táplálékforrást (felszíni egyedek baktériumfilmet, barlangi egyedek avart) kapott. A megmaradt táplálékot a teszt után eltávolítottuk, majd 48 óra múlva került sor a második tesztre, melyben felcseréltük a táplálékforrásokat. Az tesztek sorrendjét minden egyednél randomizálással alakítot- 
tuk ki. Az akklimációs idő alatt, valamint a két kísérlet között az egyedek nem kaptak táplálékot.

\section{Adatfeldolgozás}

Az egyedi táplálékpreferencia leírásához a következő egyedi változókat alkalmaztuk: (i) a táplálkozási hajlandóságot (vagyis, hogy az állat megkezdte-e a táplálkozást) és (ii) az egyedi összes táplálkozási időt. Táplálkozási eseménynek azt tekintettük, amikor az állat érintkezett a táplálékforrással és láthatóan manipulálta azt. Akkor tekintettünk befejezettnek egy táplálkozási eseményt, amikor az állat legalább egy testhossz távolságra távolodott a táplálékforrástól. Hogyha egy egyed egyértelmüen nem mutatott érdeklődést a táplálékforrás irányába a 60 perc alatt, a maximum látenciaidőt kapta (3600). Végül 49 egyed nem táplálkozott egyik kísérlet során sem, emiatt binomiális változóként kezeltük a táplálkozási hajlandóságot, ahol 1 értéket kaptak az egyedeknek, amik táplálkoztak a teszt ideje alatt és 0 értéket, melyek nem táplálkoztak ez idő alatt. A statisztikai elemzéseket az R programmal (R DEVELOPMENT CORE TEAM 2018) végeztük.

Annak tesztelésére, hogy hatással van-e a tápláléktípus és populáció az összes egyed táplálkozási hajlandóságára, egy általánosított lineáris kevert modellt használtunk, logit linkkel (NAKAGAWA \& SCHIELZETH 2010). Ebben a modellben a binomiális eloszlású táplálkozási hajlandóság volt a függö-, míg a tápláléktípus, a populációk és ezek interakciói a magyarázó változók. A random hatásokat likelihood ratio teszttel becsültük. A modellek futtatásához az lme4 és lmerTest könyvtárakat használtuk (BATES et al. 2014, KUZNETSOVA et al. 2017). Az esetleges habituáció teszteléséhez z-transzformációt alkalmaztunk a merési sorrenden (innen: sorrend), melyet önmagában és az egyeddel összefüggésben (random meredekség) is bevittük a modellbe. A random tengelymetszet (random faktorok az egyedek) és random meredekség (egyed $\times$ sorrend mint random faktorok) modelleket Khi-négyzet teszttel hasonlítottuk össze. A marginális és kondicionális $R^{2}$ értékek becslését a MuMIn könyvtár (BARTOŃ 2013) használatával, továbbá NAKAGAWA \& SCHIELZETH (2013) ajánlásait figyelembe véve végeztük. Ezt követően teszteltük a tápláléktípus és populáció táplálkozási időre kifejtett hatását a legalább egyszer táplálkozó egyedek esetében. Ehhez egy negatív binomiális eloszlást feltételező általánosított lineáris kevert modellt használtunk, log linkkel (NAKAGAWA \& SCHIELZETH 2010). A független változók a populáció, az ivar, a tápláléktípus és a kísérletek sorrendje voltak.

\section{Eredmények}

A táplálkozási hajlandóság esetében a habituáció (sorrend) szignifikáns volt (1. táblázat), az egyedek idővel hajlamosabbak voltak táplálkozni, függetlenül a táplálék típusától. A Molnár János-barlangból származó egyedek hajlamosabbak voltak táplálkozni, mint bármelyik felszíni populáció egyedei (1. táblázat, 1. ábra). Marginálisan szignifikáns különbséget találtunk az egyedi viselkedési átlagokban $\left(\chi_{1}^{2}=2,61 ; P=0,053\right)$. Az $R^{2}$ értékek alapján a fix hatások a teljes variancia 17,3\%-át magyarázzák, míg a teljes modell 29,8\%-ot magyaráz. 
1. táblázat. A víziászka populációk táplálkozási hajlamára futtatott binomiális lineáris kevert modell eredményei. A szignifikáns eredmények vastagon szedettek.

Table 1. Results of a binomial linear mixed model running on the nutritional propensity of waterlouse populations. Significant results are bold.

\begin{tabular}{lll}
\hline & $\chi^{2}(\mathbf{d f})$ & $\boldsymbol{P}$ \\
\hline Populáció & $\mathbf{2 1 , 9 7 ( 4 ) ;}$ & $<\mathbf{0 , 0 0 1}$ \\
Ivar & $0,81(1) ;$ & 0,37 \\
Táplálék & $0,11(1) ;$ & 0,74 \\
Sorrend & $\mathbf{4 , 5 6 ( 1 ) ;}$ & $\mathbf{0 , 0 3}$ \\
Populáció × Ivar & $3,88(3) ;$ & 0,28 \\
Populáció × Táplálék & $1,20(1) ;$ & 0,75 \\
Ivar × Táplálék & $0,62(1) ;$ & 0,43 \\
Populáció × Ivar × Táplálék & $2,30(3) ;$ & 0,51 \\
\hline
\end{tabular}

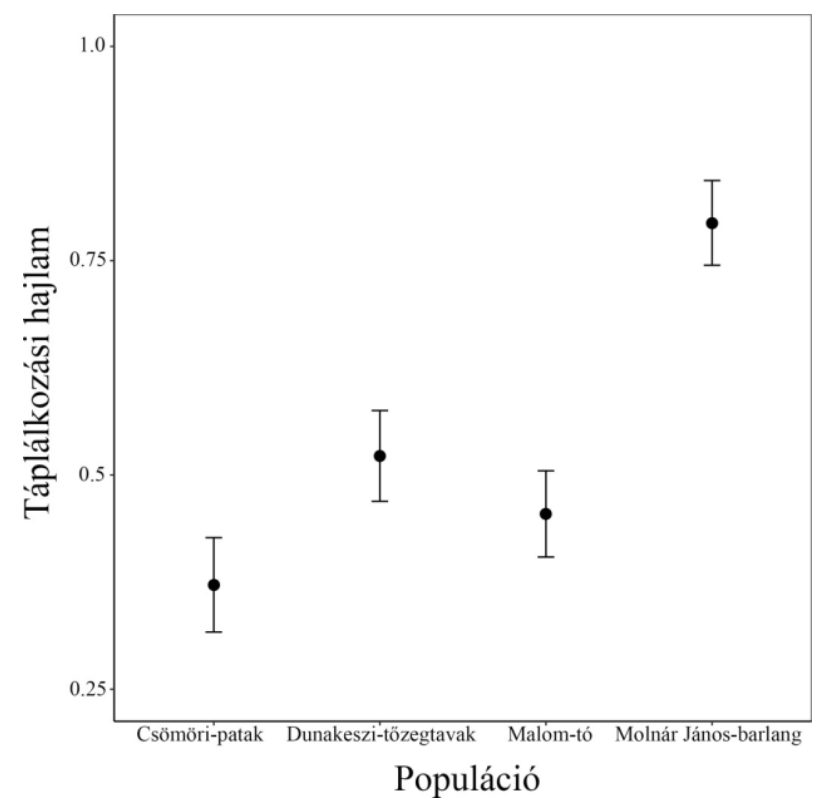

1. ábra. Táplálkozási hajlam az egyes víziászka populációkban. Az ábrán átlagok és hozzájuk tartozó standard hibák vannak feltüntetve.

Figure 1. Nutritional susceptibility in each waterlouse population. The figure shows averages and associated standard errors.

Nem találtunk szignifikáns habituációt a táplálkozási idő esetében (2. táblázat). A populáció $\times$ tápláléktípus interakciónak a táplálkozási időre szignifikáns volt a hatása (2. táblá- 
zat): felszíni populációk a szokásos tápláléktípussal, a Molnár János-barlangból származó egyedek pedig az új tápláléktípussal töltöttek több időt (2. ábra). Más szóval, mindegyik populáció a felszíni tápláléktípuson, vagyis a falevélen táplálkozott többet. Az egyedek átlagos viselkedése szignifikánsan eltért egymástól $\left(\chi_{1}^{2}=206427 ; P<0,001\right)$.

2. táblázat. A víziászka populációkon futtatott negatív binomiális kevert modell eredményei. A szignifikáns eredmények vastagon szedettek.

Table 2. Results of a negative binomial blended model run on waterlouse populations. Significant results are bold.

\begin{tabular}{lll}
\hline & $\chi^{2}(\mathbf{d f})$ & $\boldsymbol{P}$ \\
\hline Populáció & $\mathbf{2 4 4 0 ( 4 )}$ & $<\mathbf{0 , 0 0 1}$ \\
Ivar & $0,44(1)$ & 0,51 \\
Táplálék & $\mathbf{4 , 7 5 ( 1 )}$ & $\mathbf{0 , 0 2 9}$ \\
Sorrend & $2,46(1)$ & 0,12 \\
Populáció $\times$ Ivar & $1,80(3)$ & 0,61 \\
Populáció $\times$ Táplálék & $\mathbf{1 7 , 7 9 ( 1 )}$ & $<\mathbf{0 , 0 0 1}$ \\
Ivar × Táplálék & $0,40(1)$ & 0,53 \\
Populáció $\times$ Ivar $\times$ Táplálék & $2,64(3)$ & 0,45 \\
\hline
\end{tabular}

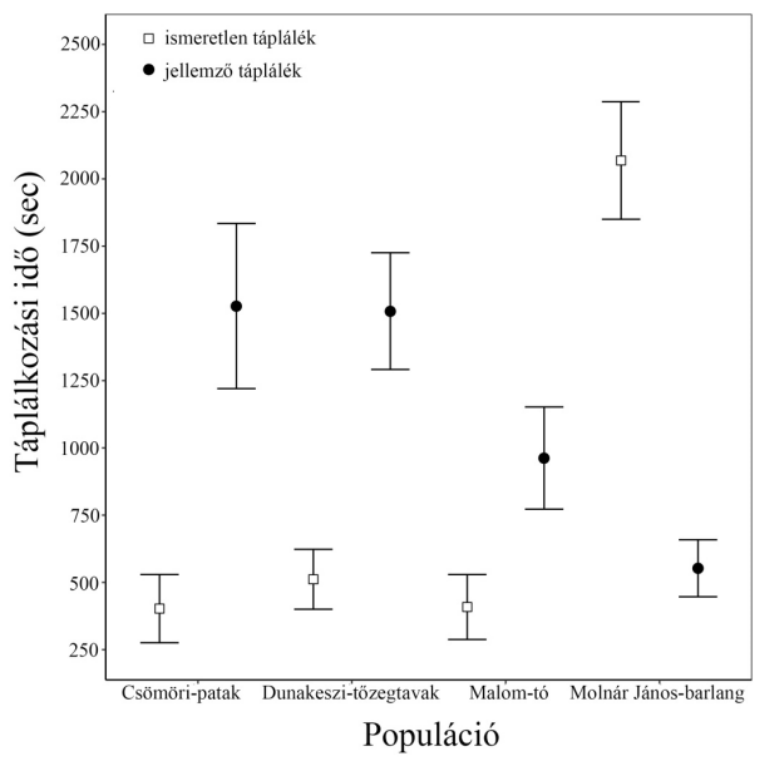

2. ábra. Az egyes tápláléktípusok kezelésével eltöltött idő az egyes víziászka populációkban.

Az ábrán átlagok és hozzájuk tartozó standard hibák vannak feltüntetve.

Figure 2. The time spent on treating each foodtypes in each waterlouse population. The figure shows averages and associated standard errors. 
A felszíni populációk táplálkozási viselkedésében nem volt szignifikáns különbség. Ugyanakkor a Csömöri-patakból származó populáció esetében trend mutatkozik az alacsony táplálkozási hajlam irányába.

\section{Értékelés}

A viselkedési innováció egyrészt lehetővé teszi minél több forrás hatékony kihasználását, ugyanakkor a megfelelő viselkedési flexibilitást biztosító központi idegrendszer energiaigényes fejlődése miatt nem elhanyagolható költségei vannak (KOTRSCHAL et al. 2013, AIELLO \& WHEELER 1995). Ezért egy olyan új élőhely benépesítése esetén, ahol az innovációs készség előnyei elvesznek, vagy látszólag minimálisak, az innovációs készség evolúciós elvesztését vártuk. Az általunk vizsgált barlangban egyetlen táplálékforrásként baktériumtörzsek szolgálnak, melyek nagy része vas- és kén-oxidáló baktérium (BORSODI et al. 2012). Ezen törzsek jelenléte a barlang magas kéntartalmának köszönhetö, és specialitásuk miatt valószínü, hogy e törzsek ismeretlenek a felszíni populációk számára. Predikciónk szerint a barlangi víziászkák (melyek a Molnár János-barlang esetében genetikailag nagyjából 140000 éve izolálódtak, és tértek át barlangi életmódra (PÉREZ-MORENO et al. 2017)) nem fogják fogyasztani a felszíni táplálékot, a felszíni víziászkák ellenben képesek lesznek váltani a barlangi táplálékforrásra. Egy közelmúltban publikált tanulmány alapján a szerves szén (total organic carbon, TOC) jelenléte mérési hibahatár alatt van a Molnár Jánosbarlangban (DOBOSY et al. 2016), ami arra utal, hogy ez esetben a külvilágból nem kerül be szerves anyag, tehát a levélavar valóban ismeretlen táplálék az ott élő állatok számára.

Egyik megfigyelésünk volt, hogy a barlangi populációban tápláléktípustól függetlenül arányaiban több egyed táplálkozott, mint bármely felszíni populáció esetében. A különböző tápláléktípusokkal töltött idő esetében predikciónkkal ellentétes eredményeket kaptunk, ugyanis a barlangi populáció egyedei is a felszíni tápláléktípust részesítették előnyben. Ebből arra következtethetünk, hogy a barlangi víziászkáknál nemcsak fennmaradt a felszíni táplálék felismerésének és elfogyasztásának képessége, de ugyanazt a preferenciát is mutatták a felszíni táplálék iránt, mint a felszíni populációk egyedei.

A barlangi egyedek jóval nagyobb arányban táplálkoztak a felszínieknél. Magyarázatul szolgálhat egy hasonló adaptáció, mint amit az Astyanax mexicanus halfaj esetében figyeltek meg. A barlangi életmódhoz alkalmazkodott egyedek jóval fejlettebb szaglással bírnak, mely nagy segítséget nyújt többek közt a táplálék megtalálásában (BIBLIOWICZ et al. 2013). Könnyen elképzelhető, hogy a közönséges víziászka is hasonló evolúciós folyamat során alkalmazkodott, és a barlangi egyedek azért táplálkoztak nagyobb arányban, mert a táplálék észlelésére szolgáló kemoszenzoros müködésük érzékenyebb, mint felszíni fajtársaiké. A Csömöri-patakból származó populáció esetében a vízáram megszünése közre játszhatott az alacsony táplálkozási hajlandóságban. Természetes élőhelyükön a víz áramlása miatt oxigéndúsabb a patak, ezáltal a Petri-csészében a csökkent elérhető oxigén stresszfaktor lehetett számukra, bár a közönséges víziászka igen rezisztens a hypoxiára (MALTBY 1995).

A barlangi populáció egyedei több időt töltöttek a számukra potenciálisan ismeretlen tápláléktípus, a levélavar fogyasztásával, mint a számukra megszokott baktériumfilmmel. MARCUS et al. (1978) eredményei alapján a levélavar tápanyagtartalma kielégítőbb a 
baktrériumfilmmel szemben, mely összhangban áll az általunk megfigyeltekkel. Ez magyarázhatja, hogy a Molnár János-barlangban élő víziászkák miért táplálkoztak többet a levélavarból, mint a baktériumfilmből. Egy másik nyomós érv lehet a levélavar preferálása mellett, hogy a baktériumfilmben nehézfém halmozódik fel, egész pontosan arzén és nikkel, mely mérgezö a víziászkák számára (MARTIN 1986; DOBOSY et al. 2016).

Összefoglalva a kutatás eredményeit, úgy sejtjük, hogy a flexibilitáshoz szükséges energiaigényből származó hátrány kisebb, mint a flexibilitás elvesztéséből adódó hátrány, vagy a flexibilitás ezen szintje elenyésző költségekkel jár. A háttérmechanizmus pontos megértéséhez további kísérletek szükségesek, melyek eredményei az evolúcióbiológiában és viselkedésökológiában hasznos és értékes információkkal bővíthetik eddigi tudásunkat.

Köszönetnyilvánítás. A kísérletek elökészítésében és megvalósításában való segítségért köszönet illeti HAJRIZ BERISHÁt. A kísérletek a NKFI SNN 125627 pályázat keretein belül valósulhattak meg.

\section{Irodalomjegyzék}

Aiello, L. C. \& WheEler, P. (1995): The Expensive-Tissue Hypothesis: The Brain and the Digestive System in Human and Primate Evolution. Current Anthropology 36: 199-221. https://doi.org/10.1086/204350

Barr, T. C. \& Holsinger, J. R. (1985): Speciation in Cave Faunas. Annual Review of Ecology and Systematics 16: 313-337. https://doi.org/10.1146/annurev.es.16.110185.001525

BARR, T. C. (1967) Observations on the Ecology of Caves. The American Naturalist 101 (922): 475491. https://doi.org/10.1086/282512

Bartoń, K. (2013): MuMIn: Multi-model inference. Version 1.9.5. Package for $R$.

Bates, D., Mächler, M., Bolker, B. \& Walker, S. (2014): Fitting Linear Mixed-Effects Models using lme4, ArXiv e-prints. arXiv:1406. 10.18637/jss.v067.i01. https://doi.org/10.18637/jss.v067.i01

Bibliowicz, J., Alié, A., Espinasa, L., Yoshizawa, M., Blin, M., Hinaux, H. \& RétauX, S. (2013): Differences in chemosensory response between eyed and eyeless Astyanax mexicanus of the Rio Subterráneo cave. EvoDevo 4: 2-7. https://doi.org/10.1186/2041-9139-4-25

Borsodi, A. K., Knáb, M., Krett, G., Makk, J., Márialigeti, K., Eross, A., \& Mádl-Szonyi, J. (2012): Biofilm Bacterial Communities Inhabiting the Cave Walls of the Buda Thermal Karst System, Hungary. Geomicrobiology Journal 29: 611-627. https://doi.org/10.1080/01490451.2011.602801

Culver, D. C. \& PiPAN, T. (eds) (2019): The Biology of Caves and Other Subterranean Habitats (2nd ed.). Oxford University Press, Oxford, $119 \mathrm{pp}$. https://doi.org/10.1093/oso/9780198820765.003.0006

Dobosy, P., SÁvoly, Z., ÓvÁri, M., MÁdl-Szonyi, J. \& ZÁray, G. (2016): Microchemical characterization of biogeochemical samples collected from the Buda Thermal Karst System, Hungary. Microchemical Journal 124: 116-120. https://doi.org/10.1016/j.microc.2015.08.004

FISHER, R. A. (ed.) (1930): The Genetical Theory of Natural Selection Oxford: Clarendon Press, 69 pp. https://doi.org/10.5962/bhl.title. 27468 
FISHER, R. A. (ed.) (1958). The genetical theory of natural selection (2nd ed.). Dover Publications, New York, 69 pp.

KENDER, J. (1939): A Szent Lukács-fürdő tavának limno-biológiai vizsgálata. Palaestra Calasanctiana 25: 1-24

Kohler, S. A., PARKer, M. O. \& Ford, A. T. (2018): Species-specific behaviours in amphipods highlight the need for understanding baseline behaviours in ecotoxicology. Aquatic Toxicology 202: 173-180. https://doi.org/10.1016/j.aquatox.2018.07.013

Kotrschal, A., Rogell, B., Bundsen, A., Svensson, B., Zajitschek, S., BrÄnnström, I. \& Kolm, N. (2013): Artificial Selection on Relative Brain Size in the Guppy Reveals Costs and Benefits of Evolving a Larger Brain. Current Biology 23: 168-171. https://doi.org/10.1016/j.cub.2012.11.058

Kuznetsova, A., Brockhoff, P. B. \& Christensen, R. H. B. (2017): 1merTest Package: Tests in Linear Mixed Effects Models. Journal of Statistical Software 82(13). https://doi.org/10.18637/jss.v082.i13

Maltby, L. (1995): Sensitivity of the crustaceans Gammarus pulex (L.) and Asellus aquaticus (L.) to short-term exposure to hypoxia and unionized ammonia: Observations and possible mechanisms. Water Research 29(3): 781-787. https://doi.org/10.1016/0043-1354(94)00231-U

Marcus, J. H., SutclifFe, D. W. \& Willoughby, L. G. (1978): Feeding and growth of Asellus aquaticus (Isopoda) on food items from the littoral of Windermere, including green leaves of Elodea canadensis. Freshwater Biology 8: 505-519.

https://doi.org/10.1111/j.1365-2427.1978.tb01473.x

MARTIN, T. R. (1986) The acute lethal toxicity of heavy metals to peracarid crustaceans (with particular reference to fresh-water asellids and gammarids). Water Research 20(9): 1137-1147. https://doi.org/10.1016/0043-1354(86)90060-6

NaKagawa, S. \& Schielzeth, H. (2010): Repeatability for Gaussian and non-Gaussian data: A practical guide for biologists. Biological Reviews 85: 935-956. https://doi.org/10.1111/j.1469185X.2010.00141.X

NaKagawa, S. \& Schielzeth, H. (2013): A general and simple method for obtaining $\mathrm{R}^{2}$ from generalized linear mixed-effects models. Methods in Ecology and Evolution 4: 133-142. https://doi.org/10.1111/j.2041-210x.2012.00261.x

Overington, S. E., Morand-Ferron, J., Boogert, N. J. \& Lefebvre, L. (2009). Technical innovations drive the relationship between innovativeness and residual brain size in birds. Animal Behaviour 78: 1001-1010. https://doi.org/10.1016/j.anbehav.2009.06.033

Pérez-Moreno, J. L., BalÁzs, G., Wilkins, B., HerczeG, G. \& Bracken-Grissom, H. D. (2017): The role of isolation on contrasting phylogeographic patterns in two cave crustaceans. BMC Evolutionary Biology 17: 247. https://doi.org/10.1186/s12862-017-1094-9

Prevorchik, S., Blejec, A. \& Sket, B. (2004): Racial differentiation in Asellus aquaticus (L.) (Crustacea: Isopoda: Asellidae). Archiv Für Hydrobiologie 160: 193-214. https://doi.org/10.1127/0003-9136/2004/0160-0193

Verovnik, R., Sket, B. \& Trontelj, P. (2005): The colonization of Europe by the freshwater crustacean Asellus aquaticus (Crustacea: Isopoda) proceeded from ancient refugia and was directed by habitat connectivity. Molecular Ecology 14: 4355-4369. https://doi.org/10.1111/j.1365-294X.2005.02745.x

WenNersten, L. \& Forsman, A. (2012): Population-level consequences of polymorphism, plasticity and randomized phenotype switching: A review of predictions. Biological Reviews 87: 756-767. https://doi.org/10.1111/j.1469-185X.2012.00231.x 


\title{
The effect of cave adaptation on the food preference of the common waterlouse (Asellus aquaticus)
}

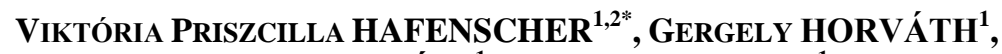 \\ GERGELY BALÁZS ${ }^{1}$ \& GÁBOR HERCZEG ${ }^{1}$
}

\author{
${ }^{1}$ Behavioral Ecology Group, Department of Zootaxonomy and Ecology, Eötvös Loránd University, \\ Pázmány Péter sétány 1/C, H-1117 Budapest, Hungary \\ ${ }^{2}$ Department of Social and Economic Geography, Eötvös Loránd University, Pázmány Péter sétány 1/C, \\ H-1117 Budapest, Hungary *E-mail: haf.viktoria@gmail.com
}

\section{ÁLLATTANI KÖZLEMÉNYEK (2020) 105(1-2): 85-94.}

\begin{abstract}
Behaviour is one of the most plastic phenotypic traits and behavioural innovation could be an important mechanism during colonization of novel environments, however, as it requires developed cognitive skills and nervous system, it has serious costs. Here, we aimed to test whether a species generalist for habitat and food sources loses its innovativeness towards food change after colonizing and adapt to a stable environment. To this end, we conducted a manipulative experiment with surface and subterranean populations of common waterlouse (Asellus aquaticus). We expected low behavioural flexibility and behavioural innovation in animals adapted to caves, as in environments with low spatiotemporal variability these are expected to yield low benefits. The pattern we got was the opposite in the populations.
\end{abstract}

Keywords: cave colonization, adaptation, phenotypic variability, food preference, environmental stability. 